\title{
Women's Reproductive Autonomy and the Ethics of Baby Making: The Nigerian Case Study
}

\author{
Chitu Womehoma Princewill ${ }^{1}$ and Ayodele Samuel Jegede ${ }^{2}$ \\ 1. National Biotechnology Development Agency, Umaru Musa Yar’Adua Express Road, Abuja, P.M.B 5118, Nigeria \\ 2. Faculty of Social Sciences, Department of Sociology, University of Ibadan, Ibadan, Oyo State, Nigeria
}

\begin{abstract}
This study originates from a larger study carried out on the autonomy and reproductive rights of married Ikwerre women of Rivers State, Nigeria. It examined the use of women for the sole purposes of making babies by couples who are unable to produce children naturally. The study explored a purposive qualitative research method. Data collection was from December 2014 to March, 2015. Thirty four (34) IDIs (in-depth interviews) and six FGDs (focus group discussions) were conducted with married Ikwerre women between the ages of 22 and 60 years with various educational backgrounds, who are either in monogamous or polygynous marriage. Data were analyzed thematically. Questions on understanding of autonomy, reasons for getting married, choice of marriage, effect of marriage, and educational qualifications were asked. Results showed that some women are married off for the sole purpose of making babies for couples who cannot have biological children. These baby making wives are often very unhappy because of the status they are made to assume after having children for these couples. A few are happy, because they see being married for whatever reason as better than being single. Adequate laws should be put in place to regulate ART (Assisted Reproductive Technology) in Nigeria. This will help eliminate the exploitation of women for baby making.
\end{abstract}

Key words: Nigeria, Ikwerre, baby making, autonomy, women, infertility.

\section{Introduction}

The practice of modern ART (Assisted Reproductive Technology) is relatively new in Nigeria. It comes with challenges of stigmatization on the couples involved, the surrogate mother, and also the children born from this arrangement [1]. Infertility is an issue that is looked upon with shame; couples who are unable to bear children seek alternative means and they do this as discreet as possible to avoid stigmatization because of the socio-cultural importance attached to natural birth [1, 2]. In Africa and indeed the Ikwerre society, having biological children is viewed as a thing of joy and victory over adversaries. A man whose wife is unable to bear children of her own is looked down and the man is mocked by friends and relatives [3]. A woman who is unable to bear children is viewed either as a witch who has eaten up all her

Corresponding author: Chitu Womehoma Princewill, $\mathrm{PhD}$, research field: women's autonomy/bioethics. children, a wayward woman who has aborted all her children or as a cursed woman whom the gods have decided to punish for a sin committed [4, 5]. In most infertile cases in Nigeria, science is brushed aside with a wave of the hand. Infertility, therefore, brings reproach to most families [6, 7]. For this reason parents secretly seek alternative means of having children. Unfortunately, this alternative means of having children in Nigeria does not only erode the woman's reproductive autonomy, but also stripes her of her dignity, subjects her to exploitation because there are no written agreements due to lack of legal laws for ART [8-10].

Previous studies on ART have not considered the traditional and culturally accepted form of ART, which is, getting an additional but younger wife for the sole purpose of making babies. This paper therefore, examines this traditional and culturally accepted way of ART.

The lack of legal framework and code for legal and 
accepted assisted reproductive technologies such as surrogacy, in-vitro fertilization, etc. have given rise to illegal baby factories in Nigeria and the use of women purportedly married for the sole purpose of making babies [11]. Even adoption, which is legal in Nigeria, is laughed at by the society and it is highly stigmatized [1, 2, 10, 12, 13]. According to Nkrumah, 2014, operation of baby factories in Nigeria raises serious ethical concerns. More worrisome is the fact that medical practitioners, the law enforcement agencies are in one way or the other involved in this illegal practice of baby factory. While the medical practitioners and the law enforcement agencies aid the operations of those who run baby factories as business ventures, the tradition/culture accepts the marrying of young ladies for the sole purpose of making babies for infertile couples [14]. This type of traditional baby making is viewed as surrogacy [2]. Surrogacy is a form of overcoming childlessness whereby another woman carries child/children for couples who are unable to have biological children of their own [15]. This type of accepted traditional surrogacy practiced amongst the Ikwerres is known as the genetic surrogacy where the surrogate mother contributes her egg [11].

Ref. [16] described baby factories as a place where babies are born and sold to couples who are unable to give birth to children of their own. Ref. [16] went further to say that, a baby factory could be a clinic/hospital, an orphanage or even secretly in private homes. Those who run baby factories are as discrete as possible and their offices are camouflaged. The girls in these baby factories are not aware of what goes on there. The girls are deceived, kidnapped or picked up from the streets [9]. On the other hand, the traditional "baby factory" is not a secret thing. The ladies involved in this traditional baby factory are aware of what they are getting involved in, their parents and family are also aware.

\section{How the Baby Factories Work}

\subsection{Hospitals/Clinics}

In this case the doctors, nurses and sometimes the caregivers are accomplices. They sell off children of un-suspecting couple and present to them a dead child or simply tell them that their babies did not make it and so have been disposed of. There are a lot of quack hospitals in Nigeria and so issues like this are common. Sometimes, healthcare givers and physicians in reputable private and government hospitals are involved in this illicit business [14, 17]. Another issue that has made baby sales in hospital possible is the fact that paternalistic medicine is still practiced in Nigeria where the physician's word is sacred. Patient's autonomy and informed consent are seen as western culture. Patients are expected to cooperate and accept what the doctor says [18].

\subsection{Wives Marry Wife for Husband}

In the Ikwerre culture, and indeed the Nigeria culture, it is a known and acceptable culture for wives who are unable to bear children for their husbands to marry a young lady who will bear children for the husband. This woman is strictly for making babies. She is usually not regarded and treated as a wife by the so called husband. She is not the responsibility of the man but she is the responsibility of the woman who "married" her for her husband [4]. The baby making woman has no form of reproductive autonomy. She understands while she is there and has no choice but to comply. The children she bears are not to call her mother and she is not to treat them as her children. She is to treat them as her bosses' children [4]. Although, she is not happy with her position in the house, she is contented because the society views her as a married woman; she has a roof over her head and food to eat.

\subsection{House Help Is Made Pregnant}

In cases like this, the couple agrees to get a young house help. Usually, this house help is a relative of the wife whose parents are poor and helpless. The parents of the young girl are given the impression that the couple will alleviate the status of the girl by giving her 
quality education and ultimately secure a job for her after her education. Once the girl begins to live with the couple, all the promises are forgotten and she is turned into a sex slave as well as a house keeper [19]. This girl who is naive, with no form of communication endures the new terrible life until the couple has the required number of children they need. She is then sent back to her poor parents who though very angry and helpless, accept their daughter back with gratitude to God that she is still alive. Ironically, in some cases, parents are aware of what their daughters will be used for, but because of poverty they force their daughters into it for financial gains.

\subsection{Secret Baby Factories}

These are operated in either individual houses or make believe motherless homes. These baby factories are usually operated by individuals, mostly women. Ladies are kidnapped and locked up [9]. Different men come to have sex with them with the sole purpose of having them pregnant. Sometimes pregnant teenagers who were driven away by their parents or guardian fall prey to these wicked operators of the baby factories. These girls are made pregnant and monitored until they give birth [14]. Once birth is completed, the babies are immediately taken from them and handed over to waiting prospective buyers. Sometimes these babies are bought and used for ritual purposes [20]. After delivery, these girls are primed for another session of baby making [21, 22].

\subsection{Adoption}

This is the only legal alternative way for infertile couple to have children. Adoption is still evolving in Nigeria, but not without stigmatization. Stigmatization and the avoidance of being in polygynous marriage are the reasons women prefer to pretend to be pregnant only to buy babies from the baby factory at the end of the purported nine months of pregnancy [23].

Previous studies on ART have not considered the culturally accepted way of alternative baby making, which is marrying a younger lady for the sole purpose of making babies. For the purposes of this study, we will concentrate on the FGD (focus group discussion) and IDI (in-depth interview) responses of women in polygynous marriage who got married for the purposes of making babies for couples who are unable to have children of their own. Invariably, we are therefore, examining the culturally accepted form of baby making.

\section{Method}

\subsection{Study Site}

This study was conducted in Rivers State, which is one of the 36 states in Nigeria. It is located in the crude oil rich Niger Delta region. It has a population of about 5.5 million [24]. Ikwerre people live in four out of the 23 Local Government Areas (LGA) of Rivers State, namely: Port Harcourt Local Government Area (PHALGA), Obio/Akpor Local Government Area (OBALGA), Ikwerre Local Government Area (KELGA), and Emuoha Local Government Area (EMOLGA) [25]. The Ikwerre people make up 27\% of the total population of the state [24]. They are in the majority and own more than 20 percent of the arable land in Rivers State [26]. The Ikwerres are traditionally ancestral worshippers, but Christianity and other religions are also practiced [27]. They speak Ikwerre, Pidgin (an adapted form of English Language) and English [27]. The Ikwerres practice both monogamous and polygynous marriages. In this study, a monogamous marriage was defined as one man married to one woman and polygynous marriage as one man married to two or more women simultaneously.

\subsection{Study Participants}

Women were eligible to participate in the study if they were married Ikwerre women, spoke Ikwerre, Pidgin or English Language and were between the ages of 22 and 60 years. Participants were purposively selected across the four Ikwerre LGAs of Rivers State. The women community leaders of the four LGAs were 
contacted. The women community leaders then recruited participants. The support of the community leaders was sought because of the sensitivity of the research topic and because participants would only participate in the study if the women leaders gave their consent. The first author briefed the women community leaders on the objectives and other information about the study.

The women community leaders then contacted a total of 90 women who fit the selection criteria and a list was prepared according to their age, educational qualifications, and type of marriage. Thereafter, the first author personally contacted all 90 women by either visiting their houses, offices or by telephone. If two or more women were married to a man, only one was chosen to avoid any conflicts that might arise in the house. A few women declined to participate due to the death of family member; others did not respond to the phone calls, and others simply refused. Out of the 90 women contacted, 57 women agreed to participate in the study. They received informed consent documents to take home to read. The first author explained the contents of the consent information to women who could not read, and they also took the documents home.

After a week, all potential participants were contacted by phone or either visited in their homes or offices to explain the study further and to check if they were still willing to participate, and if so, a possible date, time and place of interview were discussed. Signed or thumb printed informed consent was obtained from those who agreed to participate. They were also informed that they could withdraw from the study at any point and that their participation was completely voluntary. They were also informed that data collected would only be used for academic purposes and would remain confidential. Participants' recruitment was the same for IDIs and FGDs. We recruited participants who had different educational levels and were either in monogamous or polygynous marriages. Coincidentally, all participants were practicing Christians.
In the informed consent documents, participants were told to indicate if they were willing to participate in the FGD, IDI or both. Twenty-nine participants indicated willingness to participate in FGDs; 23 wished to participate in an IDI, while five agreed to participate in both an FGD and an IDI. Moreover, during the process of informed consent, they were informed that some of the IDIs and FGDs would be conducted in the presence of a male who is my co-author so that he could observe and ensure that the interviews and FGDs were going on as they should. Participants were also told that in case they were not comfortable with this arrangement, they could withdraw from the study.

\subsection{Study Design}

An exploratory design was used because we wanted to explore participants' experiences freely and in detail. The qualitative semi-structured interview guide was carefully structured around guiding research aims and further adapted after two pilot interviews. The first three FGDs were conducted to help ascertain participants' sensitivity and acceptability of the adapted interview guide questions. The IDIs and FGDs covered similar topics but were slightly adapted. The interview guide captured questions such as understanding of autonomy, capacity to exercise their autonomy, reason for getting married, reasons for remaining in marriage (if participants mentioned abuse in marriage). Prompts were sometimes used to better understand participants' responses.

\subsection{Data Collection}

Data were collected from December 2014 to March 2015 in either English or Pidgin English whichever was preferred by participants. Eight IDIs and four FGDs were conducted by the authors. The first author completed the rest of the IDIs and FGDs.

The six FGDs enabled the research team to capture collectively held views and understand salient issues that arose from participants' interactions. FGDs consisting of four to five women in each group were conducted 
with: (1) educated women in polygynous and monogamous marriages, (2) uneducated/semi-educated women in monogamous and polygynous marriages, (3) uneducated/semi-educated women in monogamous marriages, (4) uneducated women in polygynous marriages, (5) uneducated women in polygynous and monogamous marriages, and (6) educated women in monogamous marriages.

IDIs and FGDs were conducted at venues and times chosen by participants to ensure privacy and confidentiality, and in the absence of family members. IDIs lasted for approximately 40 to 60 minutes, while FGDs lasted for approximately 55 to 90 minutes. All interviews and FGDs were audio-taped with prior permission from participants and extensive notes were taken.

\section{Data Analysis}

The first step of data analysis was listening to all audio-taped interviews and FGDs, as well as reading through notes taken. Next, these audio-taped interviews and discussions were transcribed verbatim. The interviews and discussions in Pidgin English were transcribed first in Pidgin English and then translated to English. During the transcription process, a pseudonym was given to each IDI participant, but the participants in FGDs were described by their, age, education and type of marriage. The IDIs and FGDs transcripts were read thoroughly and were coded using open and axial coding techniques [28]. The coding and categorization process continued for all IDIs and FGDs, and additional codes were added if new issues emerged. During the coding process, it was realized mid-way through data analysis that data saturation was reached as no new codes and themes were emerging with the addition of new interview transcripts. Nevertheless, all the transcripts were coded. The coding process was managed using MAXQDA11 (Verbi GHBM, Berlin).

Specifically, for this analysis, codes relating to the issue of autonomy and child bearing were sorted and re-categorized. All texts falling into these codes were re-read to compare themes among different transcripts. This process resulted in two main themes: (1) participants' understanding of autonomy, (2) reason for getting married. The authors agreed to the analysis and interpretation of study results presented.

Ethical considerations and approval

As stated earlier, this study emanated from a larger study carried out when the first author was a doctoral student at the University of Basel. This study protocol therefore was first certified by the Ethik Kommission Nordwest-und Zentralschweiz (EKNZ) of Basel, Switzerland and approved by the UI/UCH Ethics Committee of Nigeria.

\section{Result}

\subsection{Understanding of Autonomy}

Judging by Beauchamp and Childress's definition of autonomy [29], which is self-rule without external interference, we can say that the women have a fair knowledge of what autonomy means. But the women added that by the Ikwerre culture it was difficult for a woman whether married or not to exercise her autonomy.

"I know that autonomy means to do whatever you want. But that is not possible in my situation as a woman who was married to bear children for her husband and his wife.” (a 35-year old uneducated woman in FGD 2)

Similarly, another participant described autonomy as:

"Autonomy means to have control of your life. As a married woman in Ikwerre land, a woman does not have the right to practice autonomy. She is either under her father, family head or her husband. She must seek consent before she does anything”. (a 45-year old uneducated woman in FGD 3)

\subsection{Reason for Marrying}

"I was forced to marry a man I did not know at the 
age of 16 because according to my parents, the couple needed children. I ran away from the house on the day the man was to come for me. Unfortunately for me, I was found after a year and dragged to the man's house. I have eight children for them. Unfortunately, they are both poor and the man is very old. Now, I am left to cater for the eight children. I regret that day and I have not stopped hating my parents for what they did to me." (A 35-year old uneducated woman in a polygynous marriage during FGD 5)

"I was an orphan living with my uncle and his wife. My uncle and his wife forced me to marry a man who was old enough to be my father. They said his first wife had only female children for him. I gave birth to six children including several miscarriages because the man needed at least two sons." (a 40-year old uneducated woman in a polygynous marriage during FGD 2)

"My husband married me to have male children for him. So I knew that I was just going to have children for him and I also know that I will not be accorded the same respect and privileges as the first wife, but I am okay with that as long as I am married. It is better than remaining single and be laughed at." (Regina, a 32-year old semi educated woman in a polygynous marriage during IDI).

"My husband's wife married me so as to have children for them because she had only one daughter. When she came to marry me, she promised to send me to school to acquire education. She promised to generally take care of me. But as soon as I got to the house and started having children, everything changed. The promise of getting education was never materialized. I began to suffer and I was treated like a slave. My children call my husband's wife mummy and call me aunty. Once you get married for the purposes of having children, you can be sure you will become a sex slave”. (Dorcas, a 35-year old uneducated woman in polygynous marriage during IDI)

A 50-year old educated woman in polygynous marriage during FGD 1 narrated her experience. She said she agreed to marry her husband as a second wife because he promised to financially take care of her education.

"I agreed to marry my husband because he promised to finance my education to whatever level I wanted. After marriage my husband began to change from good to bad. As soon as my son was born, he stopped me from going to school. I started to attend formal school secretly and refused to bear any more children for him. This got him really angry that he married a third wife. I didn't bother but continued my education until I obtained my masters.”

\section{Discussion}

The purpose of this article is to explore and highlight the plight of women who are used for the sole purpose of making babies for infertile couples. What becomes abundantly clear is the use of these women not only as sex slave but as domestic slaves.

Culturally, if an Ikwerre married couple is unable to produce children of their own, it is usually expected that the wife will source for a woman with whom the husband will have children. In some cases, the wife in the house uses her money to marry a wife for her husband. The wife in the house pays the bride price of the young lady. This is done with some promises to the girl to lure her to accept the proposal. Although, she becomes the second wife, the "husband" does not see her as his wife but as a baby making machine. The husband does not feel any sense of responsibility towards her neither is she viewed as an in-law by the husband's relatives. It is the first wife who is solely responsible for her overall wellbeing. Often times, promises made to her are not fulfilled and she gradually begins to realize what she has put herself into, but then it is late and she begins to hate herself and everything around her. This finding is similar to Baloyi’s findings that it is said that if a woman is barren, it is her responsibility to ensure that children are produced for her husband [4].

In other cases, the consent of the young girl is not 
sought. Bride price is paid to her parents and she is whisked to her new home where she begins her life as a baby making machine. She is not only used as a baby making machine but she is also made to take care of the entire house (cook, clean the house and do other chores as may be required of her). Usually, uneducated women are the ones that fall prey to arrangements like this.

\subsection{Baby Making and Women's Mental Health}

Little attention is given to women who get married for the sole purposes of having children for infertile couples. And as such, published literature is lacking in this area. Unfortunately, because the Ikwerre society despises the single, unmarried, separated, or divorced woman, most of these women who marry for the sole purposes of having children for infertile couple console themselves by the feeling of being a Mrs. Somebody. For them it is better to be married and remain with a man than to be unmarried. Being married for whatever reason gives them respect in the society and brings honour to their families. The poor women who find themselves in this situation are satisfied that, at least, shelter, and food are guaranteed. But then, they cannot be said to be happy. This finding is in line with the paper of Princewill et al. [30] on "Autonomy and Reproductive Rights of Married Ikwerre Women in Rivers State of Nigeria".

Having control over one's life is important for one's mental health [31]. According to Ref. [32], having control over one's life is a crucial determinant of health, wellbeing, and longevity. There are huge limitations placed on these women who are used as baby making machines. These women's autonomy is eroded. They are more or less used as slaves. They not only cannot decide for themselves, they have absolutely no control over the children they bear. The thought of having one's child sees one as the house keeper or a nanny and referring to another woman as mother is enough to break one's emotions, thereby causing mental instability. A more disturbing aspect is to be repeatedly raped at will irrespective of one's health and the frequency of giving birth at the will for the couple. The baby making wife becomes an object of sexual pleasure as well as baby producing "machine" [21, 22]. One link between the lack of autonomy of the baby making wife and her health is through reduced access to adequate healthcare, information, social interactions, health risk to so many pregnancies and childbirth. These women who are used as baby factories are at high risk of sexually transmitted diseases and HIV [14]. These women are in no position to negotiate the use of condom, neither are they allowed to undergo family planning. All these could be traumatizing for the woman and could lead to depression, anxiety, and malnutrition. Sometimes, in extreme cases, these women could go in sane due to deep thoughts [15].

According to WHO 2010 [34], health is not only the absence of disease or infirmity, but the total wellbeing of an individual from the physical, mental, psychological, religious, and cultural perspective. Going by the health definition of WHO 2010 [34], it could be said that these women who are used for childbearing are not healthy.

In the Ikwerre culture, most people get married for the purpose of having children and when this is not accomplished, the next option is for the man to get another wife or for the wife to get a young lady who can have children for her husband [5]. Child birth is viewed as a test of womanhood and reproductive competence. Even though the pain associated with child bearing is excruciating, most women will love to go through the experience and will talk about it with pride and joy [35]. Culture plays a very significant role in the way women who are unable to bear children handle their childlessness. Culturally, child bearing is seen as a social respect associated with envied hierarchy. Several cultures in Nigeria place high value in procreation and the inability to have children causes severe psychological stress for the couples but more on the woman. Infertility is one of the major causes of unhappiness in marriage [1]. 


\subsection{Ethical Issues in Baby Making}

Ladies who are married out for the sole purpose of making babies have little or no autonomy. Autonomy according to Beauchamp and Childress means self-rule or self-governance without external interference [30]. Eroding a woman's autonomy is robbing her of the right to decide what happens in her life and to her children. Not having control of one's life could lead to various health challenges. Commercial baby making could lead to moral confusion because those involved may not discern what is morally wrong or right when making babies [15]. Using a lady just for making babies could also lead to economic exploitation where parties involved will commercialize baby making in a way that it will become detrimental to the carrier and invariably the baby who may be seen later in life as a bought commodity or the baby could be torn in between who to call parents or who to call mother. It could also lead to psychological harm whereby the first wife may sometimes see the child as a stranger in the event that she finally gives birth to her biological child $[2,36]$. Commercial baby making erodes the dignity of the one involved and completely diminishes her autonomy [8].

The tradition of bringing in young girls to have children for infertile couples has been a long age tradition. These findings illuminate the importance of children in the Ikwerre society. It also gives an insight into the plight of women who are solely used for the purposes of making children for couples who are unable to have their own biological children due to the couple's infertility. For these women, whether their bride price was paid by the husband, his wife or his mother, their treatments are the same. Their reproductive autonomy is eroded and so is their personhood. They are reduced to sex slaves and are also exposed to all sorts of health hazards.

In the Ikwerre culture, children play a very significant role in the family structure and the presence of children in the home is seen as a core essence of marriage. A woman's reproductive function appears to be the center of her life. A married man is fulfilled when his wife's reproductive function yields results-which are children. For the Ikwerre society, a woman's reproductive function takes precedent over education, wealth etc. And so when a couple is without a child, anxiety, sadness, fear, and depression set in. Couples then begin to look for alternative means to have children. Our findings corroborate with that of Amoh-Agyei [36].

\section{Conclusion}

The pressure to get married sometimes forces these young children to accept getting into marriage for whatever reason. The emphasis laid on having ones' biological children is also a major cultural factor that should be looked into. A child should be valued and respected irrespective of how the child came into the family. Likewise the ones who have decided to nurture such child or children should not be mocked. Stigmatization is a big cultural issue.

Using women solely for the purposes of making babies in the name of tradition and culture marginalizes women and makes reproductive responsibility very heavy for them.

There is a need to promulgate rules and regulations guiding surrogacy or any form of ART in Nigeria. The laws should stipulate penalties for defaulters. Stigmatizing those who seek children through ART should be discouraged.

\section{References}

[1] Jegede, A.S., and Fayemimo, A. S. 2010. "Culturally and Ethical Challenges of Assisted Reproductive Technologies in the Management of Infertility among the Yoruba of Southwestern Nigeria." African Journal of Reproductive Health 14 (2): 126.

[2] Makinde, et al. 2016. "Baby Factories Taint Surrogacy in Nigeria.” Reproductive BioMedicine Online 32: 6-8.

[3] Callister, L. C., Khalaf, I., Semenic, S., Kartchner, R., and Vehvilainen-Julkunen, K. 2003. "The Pain of Childbirth: Perceptions of Culturally Diverse Women.” American Society of Pain Management Nurses 4: 145-54.

[4] Baloyi, E. M. 2013. "Critical Reflection on Polygamy in the African Christian Context." Southern African 
Journalof Missiology. Missionalia 41: 164-81. doi:10.7832/41-2-12.

[5] Princewill, C. W., Wangmo, T., Jegede, A., Riecher-Rössler, A., and Elger, B. S. 2019. "Bride Price Payment and Women's Autonomy: Findings from Qualitative Interviews from Nigeria.” Women \& Health $59 \quad(1): \quad 1-14$. https://doi.org/10.1080/03630242.2018.1549645.

[6] Amujiri, B. A. 2013. "Human Trafficking and Child Abuse: Their Effect on Our Nation's Image.” Journal of Religion and Human Relations18 (1): 98-105. http://www.ajol.info/index.php/jrhr/article/view/87324.

[7] Onyemachi, T. U. 2010. "Children, Status and the Law in Nigeria.” African Research Review 4 (3a): 378-98. http://www.ajol.info/index.php/afrrev/article/view/60201.

[8] Ajayi, R. A., and Dibosa-Osadolor, O. J. 2011. "Stakeholders' Views on Ethical Issues in the Practice of in-Vitro Fertilisation and Embryo Transferin Nigeria.” Afr. J. Reprod. Health 15: 73-80.

[9] Huntley, S. 2013. "The Phenomenon of 'Baby Factories' in Nigeriaas a New Trend of Human Trafficking." International Crimes Database Brief 32 (1): 6-8. Accessed November 7, 2019. http://www.internationalcrimesdatabase.org/upload/docu ments/20131030T045906-ICD\%20Brief\%203\%20-\%20 Huntley.pdf.

[10] Umeora, O. J., Umeora, M. C., Emma-Echiegu, M. B., and Chukwuneke, F. N. 2014. "Surrogacy in Nigeria: Legal, Ethical, Socio Cultural, Psychological and Religious Musings.” Afr. J. Med. Health Sci. 13.

[11] Field, M. A. 2014. "Compensated Surrogacy.” Wash. Law Rev. 89: 1155-84.

[12] Falk, G. 2001. STIGMA: How We Treat Outsiders. Prome-theus Books. Accessed November 7, 2019. http//www buffalostate.edu/so-ciology/falk.

[13] Ojelabi, O. A., Osamor, P. E., and Owumi, B. E. 2015. "Policies and Practices of Child Adoption in Nigeria: A Review Paper.” Mediterr. J. Soc. Sci. 6: 75.

[14] Onuoha, F. C. 2014. "The Evolving Menace of Baby Factories and Trafficking in Nigeria.” Afr. Secur. Rev. 23: 405-11.

[15] Burrell, C., and Edozien, L. C. 2014. "Surrogacy in Modern Obstetrics Practice." Seminars in Fetal \& Neonatal Medicine 19: 272-8.

[16] Ombelet, W., and Johnson, A. S. 2016. "Baby Factories in Nigeria: A New and Challenging Source Abuse." Reproductive Bio Medicine Online 32: 4-5.

[17] Nkrumah, B. 2014. "Ezuma the Billionaire Baby Seller. PM News. Accessed August 2, 2015. http://www.pmnewsnigeria.com/2014/01/10/ezuma-the-b illionaire-baby-seller/.

[18] Abiola, T., Udofia, O., and Abdullahi, A. T. 2014.
"Patients-Doctor Relationship: The Practice Orientation of Doctors in Kano.” Nigerian Journal of Clinical Practice 17 (2): 241-7. www.njcponline.com.

[19] Allen, A. L. 1990. "Surrogacy, Slavery, and the Ownership of Life.” Harv. J. Law Public Policy 13: 139.

[20] Makinde, O. A., Olaleye, O., Makinde, O. O., Huntley, S. S., and Brown, B. 2015. "Baby Factories in Nigeria: Starting the Discussion toward a National Prevention Policy.” Trauma Violence Abuse 18 (1): 98-105.

[21] Cristiansson, T. 2013. "Expressen Reveals Baby Factories.” [News]. Retrieved July 10, 2019. http://www.expressen.se/nyheter/exclusive-expressen-rev eals-baby-factories.

[22] Okoli, A. C., and Okpaleke. 2014. "Human Trafficking and Trajectories of Neo-slavery: The Nigerian Experience and A Political Economy Outline.” International Journal of Liberal Arts and Social Sciences 2. www.ijass.org.

[23] Oberabor, M., and Fatunde, T. 2014. "Baby Factories in Nigeria.” Vanguard News. Accessed July, 10, 2019. http://www.vanguardngr.com/2014/09/baby-factories-nig eria/.

[24] National Population Commission, Federal Republic ofNigeria. 2010. "2006 Population and Housing Census.Priority Table Volume Viii. Population by Age, Sex andType of Household (State and Local Government Area) Abuja, Nigeria.” Retrieved from www.population.gov.ng.

[25] Imma, N. O. 2006. "Architecture and Ikwerre Culture: Hidden dimensions.” Narodnaumejetno: hrvatskicasopiszaetnologijuifolkloristiku 41: 69-81. Retrieved from http://hrcak.srce.hr/24610.

[26] Okemini, E., and Adekola, G. 2012. "Violence against Women in Ikwerre Ethnic Nationality of Nigeria: Challenges for Gender Equity and Development.” Studies in Sociology of Science 3 (2): 6-12. Retrieved from http://www.cscanada.net/index.php/sss/article/view/j.sss. 1923018420120301.1445

[27] Ihemere, K. U. 2006. "An Integrated Approach to the Study of Language Attitudes and Change in Nigeria: The Case of the Ikwerre of Port Harcourt City.” In Selected Proceedings of the 36th Annual Conference on Africa Linguistics, ed. O. F. Arasinyin and M. A. Pemberton, Somerville, M A: Cascadilla Proceedings Project. www.lingref.com.document\#1426.

[28] Strauss, A., and Corbin, J. 1990. Basics of Qualitative Research: Grounded Theory Procedures and Techniques, 2nd ed. Thousand Oaks, CA: SAGE Publications.

[29] Beauchamp, T. L., and Childress, J. F. 2009. Principles of Biomedical Ethics, 6th ed. New York: Oxford University Press, 79-81, 99.

[30] Princewill, C. W., Jegede, A. S., Wangmo, T., Riecher-Rsler, A., Elger, B. S., et al. 2016. “Autonomy 
and Reproductive Rights of Married Ikwerre Women in Rivers State of Nigeria.” Bioethical Inquiry 14 (2): 205-15. doi: 10.1007/s11673-017-9779-8.

[31] Whitehead, M., Pennington, A., Orton, L., Nayak, S., Petticrew, M., Sowden, A., and White, M. 2016. "How Could Differences in 'Control over Destiny' Lead to Socioeconomic Inequalities in Health? A Synthesis of Theories and Pathways in the Living Environment." Health \& Place 39: 51-61. doi:10.1016/j.healthplace.2016.02.002.

[32] Sen, A. 1999. "Critical Reflection-Health in Development." Bull. World Health Organization 77 (8): 619-623.

[33] Marmot, M. 2004. "Status Syndrome. How Social Standing Affects our Health and Longevity.” Bloomsbury,
London.

[34] World Health Organization (WHO). 2010. Trends Inmaternal Mortality: 1990 to 2008: Estimates Developed by WHO, UNICEF, UNFPA, and the World Bank. Geneva, Switzerland: WHO.

[35] Amoh-Agyei, G. 2004. "Evaluation of Comprehensive Emergency Obstetric Care in the Mampong District Hospital.” Unpublished postgraduate thesis, Kwame Nkrumah University of Science and Technology.

[36] AFP: Agence France-Presse. 2013. Nigeria Frees 16 in "Baby Factory" Raid. Accessed November 3, 2014. http://www.news24.com/Africa/News/Nigeria-frees-16-in -baby-factoryraid-20130620. 